\title{
Greek Armament from the South of the Iberian Peninsula during the 1st Millennium BC
}

\author{
By Juan Antonio Martín Ruiz* \\ Juan Ramón García Carretero ${ }^{\dagger}$
}

\begin{abstract}
We study the scarce Greek armament found in the southern Iberian Peninsula dated along the first half of the 1st millennium $B C$, more specifically between the seventh and sixth centuries BC. during the so-called Orientalising period. This armament consists of four Corinthian helmets which were made in the Peloponnese and the Hellenic colonies located in Magna Graecia. They were found both in indigenous aquatic contexts as ritual religious offerings -such as those coming from Ria de Huelva and Guadalete and Guadalquivir rivers- or Phoenician contexts as it happens with a tomb excavated in the colony of Malaca. To them we can add an armour breastplate which can be included in the "muscled" type, which comes from a wreck, sunk in the waters of Almuñécar, perhaps also Phoenician. Although the debate continues among researchers currently, its parallelism with what has been proposed for other areas of the Mediterranean where these Corinthian helmets have also been found means that, rather than with the direct presence of Greek warriors, as has sometimes been suggested, relate them to the indigenous and Phoenician populations that lived in these places, in particular with the ruling elites of both communities. The same happens when it comes to determining the way in which they arrived to these western territories, considering that it was mostly in the hands of Phoenician merchants but without absolutely discarding the leading role that Greeks themselves could have had in distributing such valuable products.
\end{abstract}

\section{Introduction}

The far end of the western Mediterranean was for ancient Greeks a hidden and mysterious place where they located the imaginary boundaries of the known world, as the mythical Pillars of Hercules, and therefore it housed some of their myths. One such place was the south of the Iberian Peninsula where the demigod himself came to steal the oxen from Gerion, the legendary king of Tartessus, as part of his twelve labours ${ }^{1}$. But at the same time as mythical space it was also a physical space reached by navigators as Colaeus of Samos, who according to ancient literary sources established friendly trade relations with Tartessian ruler Arganthonios returning to his homeland laden with riches. Naturally, besides Colaeus, this spot was also reached by other traders who ended up founding two colonies further north in the Gulf of Leon, Rodes and

\footnotetext{
*External Consultant, Valencia International University, Spain.

${ }^{\dagger}$ Researcher, Institute of Ronda and Serrania Studies, Spain.

1. F. González de Canales Cerisola, "El lejano occidente en la cosmografía mítica griega anterior al viaje de Coleo de Samos" ["The far west in the Greek mythical cosmography before Colaeus of Samos voyage"], Huelva en su Historia, no. 7(1999): 12-90.
} 
Emporion $^{2}$, while Mainake, once considered the most westerly Greek colony is valued today as the Greek name of a Phoenician settlement, either Toscanos, Malaga or Cerro del Villar ${ }^{3}$. As a result of those contacts, a series of materials manufactured mostly by Greek potters also reached these shores, including small bronze pieces and the arms which will be studied in these pages.

We can appreciate how these war elements are concentrated in a very specific historical period such as the Orientalising phase with a chronology, as we shall see later, placed between the $7^{\text {th }}$ and $6^{\text {th }}$ centuries BC, although it is possible to find representations made on different materials such as ivory, clay discs and vessels, some of which can be dated in more recent times. However, despite the studies of Greek colonization in the Iberian Peninsula and the extensive scientific literature, the truth is that no one has attempted to study such findings monographically yet, thus we fill a gap in the research on the subject, especially if we consider that, although they are certainly not very abundant, these pieces can offer important historical information about the relations between both ends of the Mediterranean sea.

\section{Greek Armament in Andalusia}

A total of four helmets all belonging to the Corinthian type and showing different subtypes have been attested so far, as well as a cuirass breastplate of muscle type. All of them come from the south of the Iberian Peninsula and have been published in depth so we will omit excessive details about their features. In all cases they are made of bronze even though only the composition of two of these helmets has been analyzed so far, showing that they correspond to binary bronze, a fact that is corroborated by the information provided by other helmets found in different spots away from this area as we will see later.

The first discovery of these helmets took place in 1930 during the dredging made at the Huelva port and it is now preserved in the funds of the Real Academia de la Historia. Belonging to B2 Pflug type ${ }^{4}$ and Stufe I type, it has been considered a manufacturing work of Greek metallurgists in southern Italy. It was partially recovered and offered some ornaments consisting of circles accompanied by palmettes and lotus flowers, motifs observed in other helmets deposited in Olympia as well ${ }^{5}$, at the same time showing very light and

2. X. Aquilué, "Las colonias griegas en Iberia" ["The Greek colonies in Iberia"], in Iberia Graeca. El legado arqueológico griego en la Península Ibérica (Girona, Centro Iberia Graeca, 2012), 47-55.

3. M. E. Aubet Semmler, "Mainake, la primera Malaka" ["Mainake, the first Malaka"], in Tuvixeddu, la necropoli occidentale di Karales (Cagliari, E. de la Torre, 2000), 31-40.

4. H. Pflug, "Korinthische Helme" ["Corinthian helmet"], in Antike Helme. Sammlung Lipperheide und andere Bestände des Antikenmuseums Berlin. Monographien des RGZM, 14, Mainz, 1988: 75.

5. P. Amandry, "Casques grecs à decor gravé" ["Greek helmets with engraved decoration"]. Bulletin de Correspondance Hellénique, no. 73(1949): 439-441. 
anatomical features which make it receive a date of the second half of the $6^{\text {th }}$ century $\mathrm{BC}^{6}$.

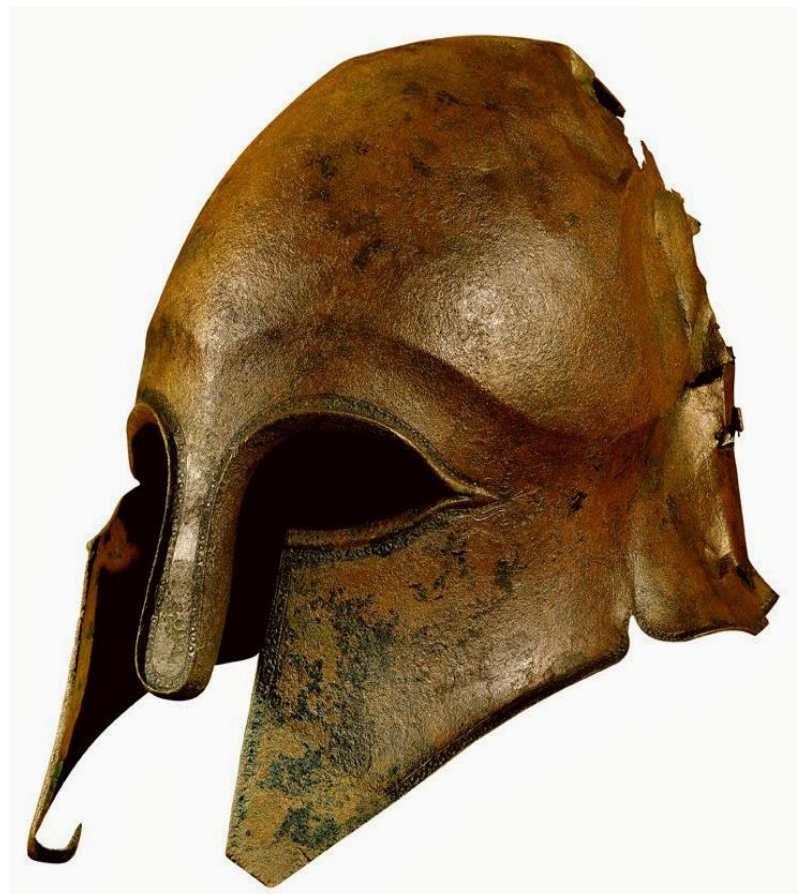

Figure 1. Corinthian helmet found at the Huelva estuary Source: Real Academia de la Historia.

A few years later, in 1939, another helmet was found on the west bank of the mouth of the Guadalete River, specifically in a place called La Corta, nowadays displayed in the Archaeological Museum of Jerez de la Frontera. It was classified under the Stufe II type which was dated in the beginning of the $7^{\text {th }}$ century $\mathrm{BC}$ and was considered to have been made in Greece itself, particularly in the Peloponnese ${ }^{7}$. Taking into consideration the still preserved rings, it must have been covered with an eye-catching plume as usual in this type of pieces. We can appreciate a series of perforations intended either to be hung on a wall or, as seems more acceptable, to sew a fur lining to make it more comfortable to wear and reduce as far as possible the impact on the

6. R. Graells i Fabregat, Mistophori ex Iberias. Una aproximación al mercenariado hispano a partir de las evidencias arqueológicas (s.VI-IV a. C.) [Mistophori ex Iberias. Approach to the hispanic mercenary armies from the archaeological evidence (6th-4th cent. $B C)$ ] (Venosa, Osanna Edizioni, 2014), 98; A. García y Bellido, Los hallazgos griegos en España [Greek findings in Spain] (Madrid, 1936), 26-27.

7. R. Graells i Fabregat, Mistophori ex Iberias. Una aproximación al mercenariado hispano a partir de las evidencias arqueológicas (s.VI-IV a. C.), 1999, 97-98; C. Pemán, Hallazgo de un casco griego en el Guadalete y recapitulación de testimonios sobre la presencia de los griegos en Andalucía en los siglos VII-VI a. C. [Finding of a Greek helmet in the Guadalete and recapitulation of testimonies about the presence of Greeks in Andalusia in the 7th-6th centuries BC] (Cádiz, 1938), 2-3; R. Graells i Fabregat, and A. J. Lorrio Alvarado, "El casco celtíbero de Muriel de la Fuente (Soria) y los hallazgos de cascos en las aguas de la Península Ibérica" ["The Celtic-Iberian helmet from Muriel de la Fuente (Soria) and the findings of helmets in waters of the Iberian Peninsula"], Complutum, 24, no. 1(2013): 151-173: 159. 
warrior's head in case the helmet received a blow during the fight. An interesting fact is the presence of a larger hole on its right side that initially was interpreted as evidence of a wound caused by a weapon that ended the life of its possessor, but we would most likely associate it to a ritual disablement before being thrown to water.

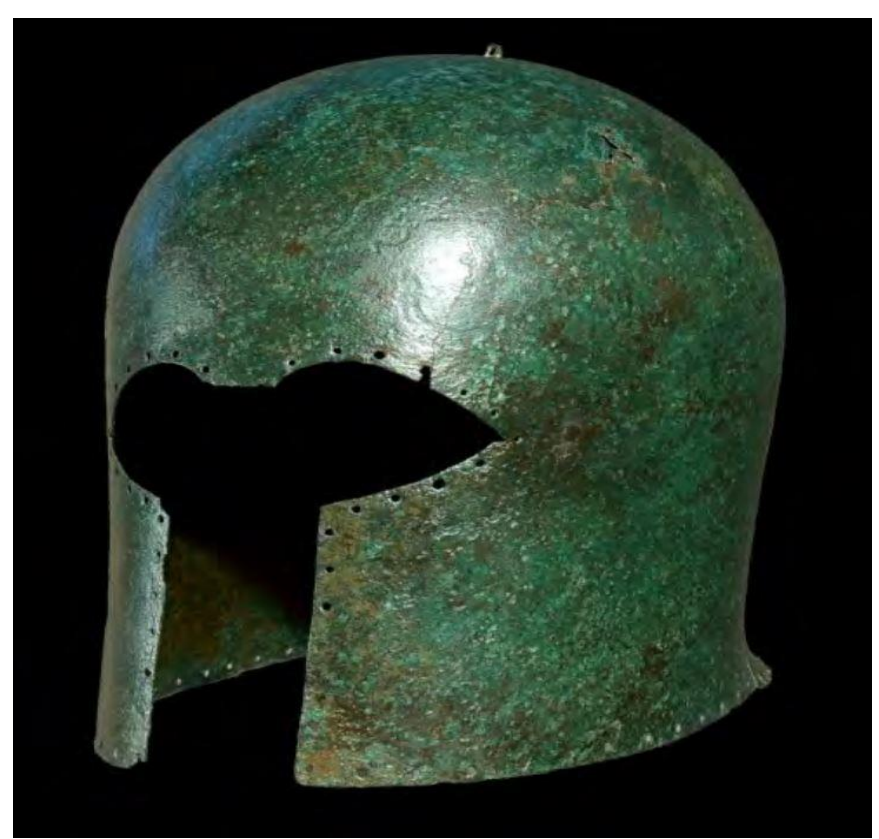

Figure 2. Corinthian Helmet Found at the Guadalete River Source: Museum of Jerez.

A new helmet, this time considered an Etruscan-Corinthian production and preserved in a private collection, was acquired in an antique shop in the seventies decade of the last century as having been found in the mouth of the Guadalquivir river, specifically near the town of Sanlucar de Barrameda in Cadiz province. Its appearance is similar to that of Huelva although it has been dated a little earlier, in about the middle of the $6^{\text {th }}$ century BC. Some remnants of the original lining have been preserved and at least two modern repairs have been identified, offering data about its binary bronze with a low percentage of tin, between $12-13 \%^{8}$.

The last helmet from the south of the Iberian Peninsula, housed in the Malaga Provincial Archaeological Museum, was recently found in a burial at the Phoenician colony of Malaga, offering a similar chronology as has been dated in the mid-sixth century BC classified into the Lotusblüten-Gruppe or Stufe II type, was part of the grave goods of a man who had been buried inside a cist. Judging by the still preserved rivets it had a crest and was also decorated with a palmette, two snakes and several birds that, as in the case of the Huelva specimen, were found in helmets preserved in Olympia as well ${ }^{9}$. In addition,

8. R. Graells i Fabregat and A. J. Lorrio Alvarado, op. cit., 159; A. Tiemblo Magro, "Un nuevo casco griego de bronce posiblemente hallado en España" ["A new bronze Greek helmet possibly found in Spain"], Revista de Arqueología, 158(1994): 34-35.

9. P. Amandry, Casques grecs à decor gravé, 1949, 439-441. 
other war elements such as an iron spearhead and possibly a shield were found next to it, being a southern Italy workshop production which had been made from a binary bronze with very little tin according to the tests, also detecting iron slag, although these amounts are not specified ${ }^{10}$.

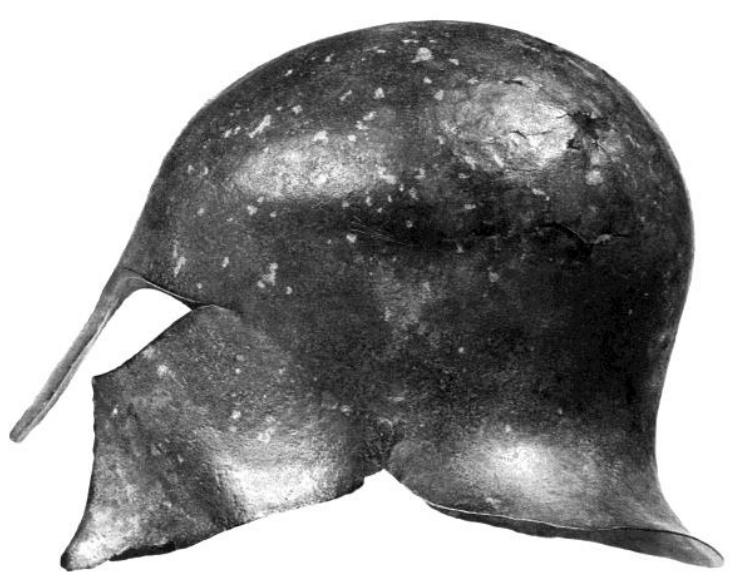

Figure 3. Corinthian Helmet from Guadalquivir River Source: Tiemblo Magro.

Finally, in connection with these helmets, we must admit that we do not dare to include in these pages the specimen from the Celtiberian necropolis of Aguilar de Anguita in the province of Guadalajara, since despite the existence of some formal similarities its poor condition does not rule out its adscription to other types ${ }^{11}$, without forgetting that the context in which it was found must be dated in a much more recent period than the others.

10. R. Graells i Fabregat, Mistophori ex Iberias. Una aproximación al mercenariado hispano a partir de las evidencias arqueológicas (s.VI-IV a. C.), 2014, 97-98; D. García González, S. López Chamizo, A.Cumpián Rodríguez and P. J. Sánchez Bandera, "La tumba del guerrero. Un hallazgo de época protohistórica en Málaga" ["The warrior's grave. A protohistoric times finding in Málaga"], Mainake, XXXIV(2013): 8-11; C. Rodríguez Segovia and E. Núñez Pariente de León, "Estudio y restauración del casco griego del museo de Málaga" ["Study and restoration of the Greek helmet from Málaga Museum"], PH Investigación. Revista del IAPH para la investigación del patrimonio cultural, 88, (2015): 128-145.

11. M. Barril Vicente, "Cascos hallados en necrópolis celtibéricas conservados en el Museo Arqueológico Nacional de Madrid" ["Helmets found in Celtic-Iberian necropolises preserved in Madrid National Archaeological Museum"], Gladius. Estudios sobre armas antiguas, armamento, arte militar y vida cultural en oriente y occidente, XXIII(2003): 8-26. 


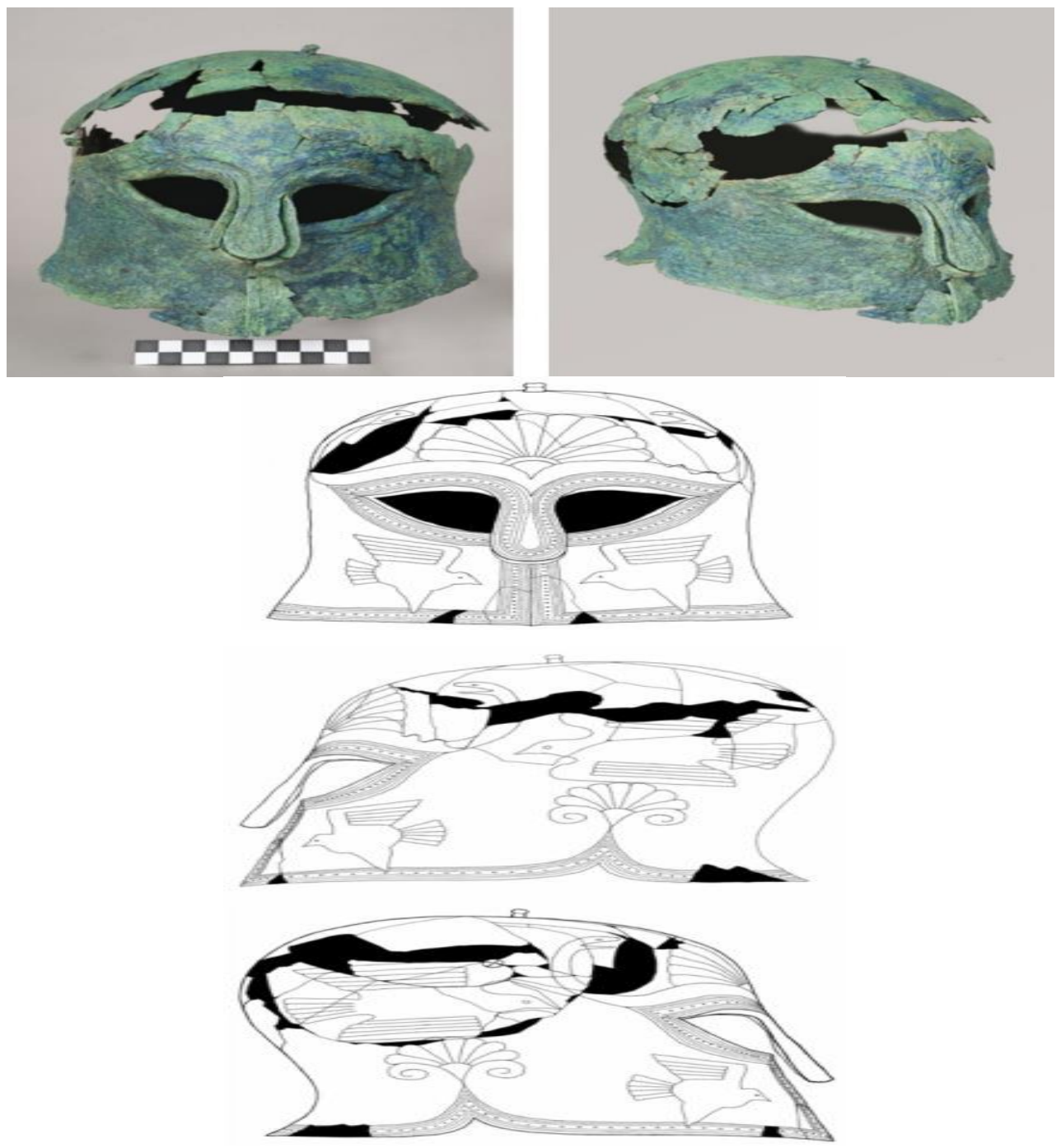

Figure 4. Photographs and Drawings of the Malaga Corinthian Helmet Source: Rodríguez Segovia and Núñez Pariente de León.

As for the only cuirass known so far in the most western end of the Mediterranean, we can state it was discovered in 1967 on the coast of Almuñecar, more specifically in the area in front of the so-called Cueva del Jarro. It is currently exhibited in one of the showcases of the Provincial Archaeological Museum of Granada and it is likely to have been part of the cargo of a wreck sunk in these waters. It corresponds to the front plate of an anatomical chest guard belonging to the so-called "muscle" type without any decoration, except for two small incised circles at the height of the chest. It has two openings on the sides for the arms, another for the neck and also has its lower edge a bit raised to prevent friction with the body. We can observe the remains of two of the four primitive hinges which are located next to the armpits and hips to attach this part to the rear by means of small bronze nails. Although at first it was dated in the $5^{\text {th }}$ century BC, other authors subsequently discussed that it should be dated a century before due to the chronology provided by a series of Phoenician-related amphorae collected nearby 
corresponding to the types T10.2.1.1 and T10.2.2.1 ${ }^{12}$. It has been suggested that, being a very common type in southern Italy, it could have come from that area although it is not possible to determine whether their presence is due to a commercial activity, or corresponds to the belongings of one of the returning Iberian mercenaries or even of the captain of the ship ${ }^{13}$.

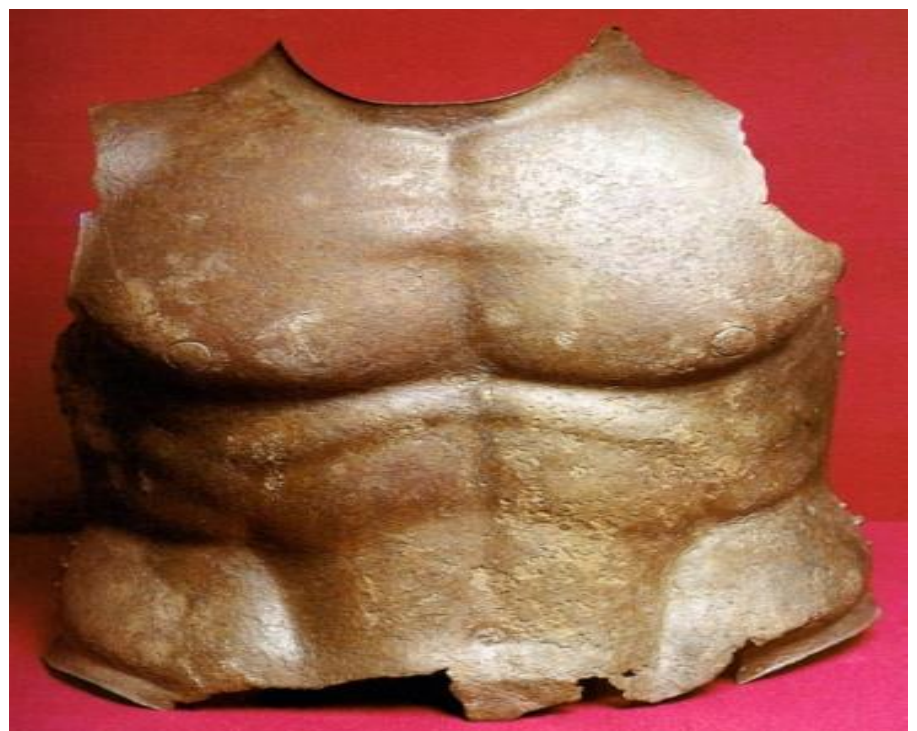

Figure 5. Front Plate of Body Armour Found off the Almuñecar Coast Source: Martín Ruiz.

Before delving into the historical study of these arms found in the south of the Iberian Peninsula, we should mention several representations of Greek weapons also attested in the western far end and manufactured on different materials. Regarding this, we can mention a box or casket from the Tartessian necropolis of Bencarron (Seville), which has been dated between the $7^{\text {th }}$ and $6^{\text {th }}$ centuries BC, depicting a kneeling warrior armed with spear and shield who is facing a lion and carrying one of these helmets fitted with a large plume ${ }^{14}$. To this ivory plate we can add a clay disc from the Phoenician settlement of Cerro del Villar dated in the $6^{\text {th }}$ century BC where we can see, along with other features, a galloping rider protecting his head with one of these helmets with a

12. J. Maluquer de Motes, "La coraza griega de bronce, del Museo de Granada" ["The Greek bronze cuirass from Granada Museum"], Zephyrus. Revista de Prehistoria y Arqueología, XXV(1974): 321-3123; A. J. Parker, Ancient Shipwrecks of the Mediterranean and the Roman Provinces (Oxford, B.A.R, 1992), 156; J. A. Martín Ruiz, Catálogo documental de los fenicios en Andalucía [Documentary catalogue of Phoenicians in Andalusia] (Sevilla, Junta de Andalucía, 1995), 87 and 152; J. Ramón Torres, Las ánforas fenicio-púnicas del Mediterráneo central y occidental [The Phoenician-Punic amphorae in Central and Western Mediterranean] (Barcelona, Universitat de Barcelona, 1995), 77.

13. B. Collado Hinajeros, Guerreros de Iberia. La guerra antigua en la Península Ibérica [Iberian Warriors. Ancient war in the Iberian Peninsula] (La Esfera de los Libros, Madrid, 2018), 180.

14. M. E. Aubet Semmler, "Marfiles fenicios del Bajo Guadalquivir (y III): Bencarrón, Santa Lucía y Setefilla" ["Phoenician ivories from Lower Guadalquivir (and III): Bencarrón, Santa Lucía and Setefilla"], Pyrenae. Revista de Prehistoria i Antiguitat de la Mediterrània, no. 17-18, (1980-81): 240-241. 
great plume ${ }^{15}$, item which can be related to another with similar chronology and features found on the island of Ibiza ${ }^{16}$. Also from this island, we can mention a scarab that could be dated in the $5^{\text {th }}$ century BC in which a warrior fitting his ocreae, armed with a shield and holding a Corinthian helmet between his legs was engraved ${ }^{17}$. All without forgetting to mention a pottery shard belonging to a cup decorated with Attic red-figure technique discovered in the Iberian settlement of Cabezo de Alcala (Azaila, Teruel), which has been dated in the $4^{\text {th }}$ century $\mathrm{BC}$, inside which a bearded warrior wearing a Corinthian helmet was painted ${ }^{18}$, and several lekythoi dated in the $5^{\text {th }}$ century BC and recovered in the necropolis of the Greek colony of Emporion belonging to the Haimon group in which hoplites helmets were depicted ${ }^{19}$. However, it should be taken into consideration that both the ivory plate and the clay discs were manufactured in western Phoenician workshops, which does not happen with the cup and lekythoi that were made in Greek territory and thus reflect the military historical reality within that area which is not of our interest now.
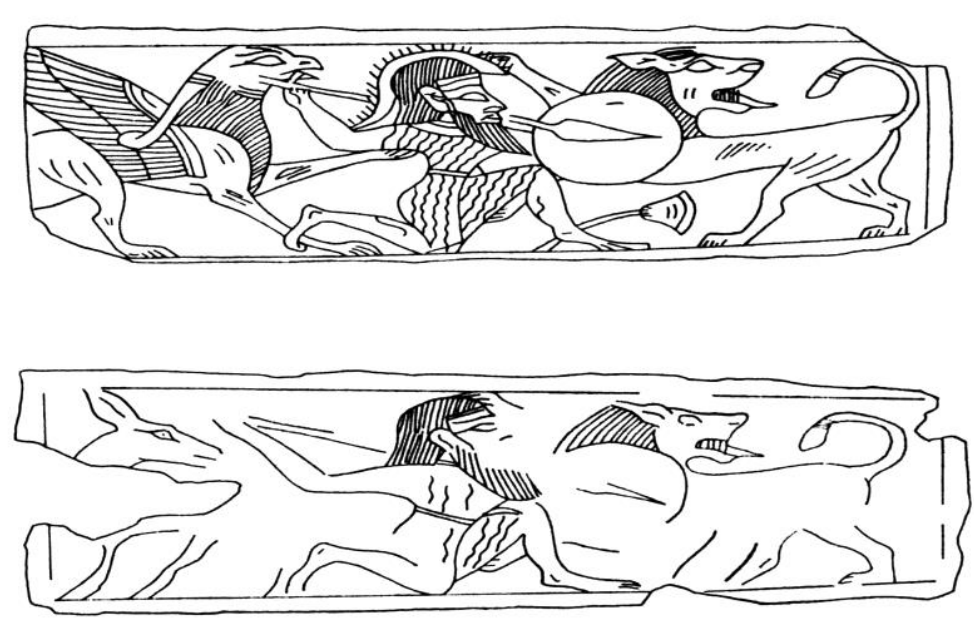

Figure 6. Ivory Plate from Bencarron

Source: Aubet Semmler.

15. A. Arribas, and O. Arteaga, El yacimiento fenicio de la desembocadura del río Guadalhorce (Málaga) [The Phoenician site on the Guadalhorce river mouth (Málaga)] (Granada, Universidad de Granada, 1975), 89-90.

16. J. M. Blázquez Martínez, "Dios jinete púnico sobre disco de Ibiza" ["Punic rider god on a disc from Ibiza"], Zephyrus. Revista de Prehistoria y Arqueología, 17(1966): 101-103.

17. J. M. Blázquez Martínez, "Escarabeos de Ibiza" ["Ibiza scarabs"], Zephyrus. Revista de Prehistoria y Arqueología, no. 21-22(1970-1971): 315-319.

18. E. M. Giménez, "Aproximación al estudio de la cerámica ibérica en el Bajo Aragón: relaciones comerciales, importaciones y clasificación" ["Approach to the study of Iberian pottery in Lower Aragón: relations, imports and classification"], Salduie. Estudios de Prehistoria y Arqueología, 10(2010): 78.

19. G. Trías de Arribas, Cerámicas griegas de la Península Ibérica [Greek pottery from the Iberian Peninsula] (Valencia, The Willian L. Bryant Foundation, 1966), 66-67. 
At this point we must wonder how those described arms reached this territory and who could have been their owners or the use they were given when acquired within either an indigenous or Phoenician society. Regarding the first question, we must recognize that the hypotheses have changed significantly in the last decades, as it was initially valued their clear belonging to Greek warriors who would have reached the western far end ${ }^{20}$. Therefore, some researchers have related these helmets to Phocaean trade stating that Herodotus (I, 163) meant that if these Greek sailors had reached the shores of ancient Onuba in warships, the presence of these helmets would not be strange $^{21}$. He was referring to the famous penteconters that despite its military character also had a certain capacity but obviously much lower than that of merchant ships, which was compensated with higher speed ${ }^{22}$. However, the fact is that today, at least in the south of the Iberian Peninsula, there is a trend to relate them to the Phoenician trade and not to a direct presence of Greek population, belief which is reinforced by the finding of the Greek cuirass breastplate off the coast of Almuñecar, always with caution as it was not found during an archaeological excavation, being most likely to be part of the cargo of a sunken Phoenician ship off the coast of Almuñecar judging by the containers of the type T10.2.1.1 and T10.2.2.1 recovered there which could be dated in the $6^{\text {th }}$ century $\mathrm{BC}^{23}$. To this circumstance we should add that nowadays it is considered that other Greek products, as pottery, came to these shores mostly in Phoenician or Carthaginian ships, as exemplified by El Sec wreck, sunk in waters of Mallorca island, which can be chronologically placed in the $4^{\text {th }}$ century BC and in which much of her cargo was precisely black-glazed Attic vessels $^{24}$.

As for the second question raised, to try to discern who could be their owners, we consider appropriate to establish differences between those located in Phoenician sites from those we can relate to indigenous contexts. Thus, in the case of the helmet discovered in the Phoenician colony of Malaga it would be in the view of the authors an aristocratic warrior but without stating whether it was Phoenician or Greek. To explain that, they discuss, apart from the logical presence of arms in this burial, the representation of the warrior goddess Sekhmet in a scarab that was part of his grave goods ${ }^{25}$. However, without

20. C. Pemán, Hallazgo de un casco griego en el Guadalete y recapitulación de testimonios sobre la presencia de los griegos en Andalucía en los siglos VII-VI a. C, 1938, 2 and 8; J. Mancebos Dávalos, "Armas defensivas en el Bajo Guadalquivir durante el período tartésico" ["Defence weapons in Lower Guadalquivir during the Tartessian period"] Antiquitas, no. 9, (1998): 29.

21. J. Fernández Jurado, La presencia griega arcaica en Huelva [The archaic Greek presence in Huelva] (Huelva, Diputación Provincial, 1984), 49.

22. J. Alvar Ezquerra, "Los medios de navegación de los colonizadores griegos" ["The navigation methods of Greek settlers"], Archivo Español de Arqueología, 52, no. 1(1979): 82-85. $1995,77$.

23. J. Ramón Torres, Las ánforas fenicio-púnicas del Mediterráneo central y occidental,

24. A. Arribas, G. Trías, D. Cerdá, and J. Hoz, de, El barco de El Sec (costa de Calviá, Mallorca). Estudio de materiales [The Sec ship (Calviá coast, Majorca). Study of material remains] (Palma de Mallorca, Ayuntamiento de Calviá, 1987), 198-360.

25. García González et al., La tumba del guerrero. Un hallazgo de época protohistórica en Málaga, 2013, 283. 
denying the outstanding character of this individual, we believe it is difficult to accept that the incised motif in that scarab can be a reliable argument because, as it has been noted ${ }^{26}$, we should not forget the problem of "iconographic vagueness" that this goddess has in relation to other Egyptian deities such as Mut, Tefnut and, above all, Bastet, because apart from its warrior character Sekhmet also has a high protector role as a deity who can cure diseases.

In this regard, the absence of the necessary DNA analysis that would clarify without any doubt his ethnicity, we should bear in mind that both the grave goods deposited inside this Malaga burial, except its weapons, and the typology of the grave itself has no differences with what we found in other more recent tombs of the same city ${ }^{27}$, so we consider more suitable to value that he could be a Phoenician individual. Although relations among Phoenicians and Greeks have been considered as a clear rivalry, stressing the role that Greek mercenaries played in the conflicts of the Phoenician colonies installed in the central Mediterranean, including Carthage, the truth is that for much of the $1^{\text {st }}$ millennium $\mathrm{BC}$ these relations were collaborative, to the extent that Greeks lived in Sulcis. All this makes it difficult to discern who might be their owners $^{28}$ as with specimens discovered on the island of Sardinia, where in 1810 three of these $6^{\text {th }}$ century BC helmets were accompanied by greaves and spearheads inside a burial chamber at the necropolis of San Antioco in Sulcis ${ }^{29}$.

Similarly, it has been suggested that some helmets located among Etruscans $^{30}$, must be related to their elites as seen in tombs of Populonia where along the $7^{\text {th }}$ century BC several people were buried with Greek helmets, shields and greaves. Something similar to what is suggested for the south of the Iberian Peninsula where they have also been linked with Tartessian elites as possible gifts ${ }^{31}$, and even among the population of southern France ${ }^{32}$, because we must not forget that throughout antiquity armament has been closely associated with power ${ }^{33}$. Regarding the different end given to these helmets, it is interesting to see how those found within indigenous areas appear in an

26. M. I. López Grande, F. Velázquez, J. H. Fernández, and A. Mezquida, Amuletos de iconografía egipcia procedentes de Ibiza [Amulets with Egyptian iconography from Ibiza] (Ibiza, Museo de Ibiza, 2014), 321-328.

27. J. A. Martín Ruiz, "Malaca," in Dizionario Enciclopedico della Civiltà Fenicia. An Encyclopedia Dictionary of the Phoenician Civilization, ed. P. Xella (Roma, C. N. R., 2014), 4-5.

28. A. J. Domínguez Monedero, "Fenicios y griegos en occidente: modelos de interacción" ["Phoenicians and Greeks in the west: interaction models"], in Contactos en el extremo de la Oilouméne. Los griegos en occidente y sus relaciones con los fenicios (Ibiza, Museo de Ibiza, 2003), 13 and 24.

29. P. Bartoloni, "L'esercito, la marina e la guerra" ["The army, the navy and the war"], in I fenici, (Milano, ed. Bompiani, 1988), 163; F. J. Jiménez Ávila, La toréutica orientalizante en la Península Ibérica [The orientalising bronze work in the Iberian Peninsula] (Madrid, Real Academia de la Historia, 2002), 238-239.

30. A. C. Cienforini, "La cultura de los príncipes" ["The culture of the princes"], in Los etruscos (Madrid, Ministerio de Cultura, 2013), 32-33 y 138.

31. F. J. Jiménez Ávila, La toréutica orientalizante en la Península Ibérica, 2002, 238.

32. D. García, "Le casque corinthien des Baux-de-Provence" ["The Corinthian helmet from Baux-de-Provence"], in L'Occident Grec de Marseille à Mègara Hyblaea (Arles: ed. Errance, 2013), 88-89.

33. Z. Zyguslki Jr., "Armour as a Symbolic Form," Waffen und Kostümkunde, 26, no. 2(1984): 79. 
aquatic environment, a fact that has been linked to offerings by sailors to the waters or to oracles or coastal sanctuaries ${ }^{34}$, although some authors have suggested that the breaking and crushing which affected the Huelva estuary helmet could have been done during a combat ${ }^{35}$. These offerings represent the continuation of a tradition that has its roots in the Late Bronze Age, so they would have got there thrown by their owners without being associated with other materials, and to render it useless in a ritual ${ }^{36}$, except for the only cuirass we know because it comes from a sunken ship and not from a voluntary offering. This is totally in tune with the helmets of this type found in Greek sanctuaries where they were deposited equally as offerings, and showing signs of ritual breaking ${ }^{37}$. As for the only helmet found so far in a Phoenician environment as Malaga, it appears in a funerary context as happens in the case of Sulcis, so we should distinguish a different purpose depending on their cultural context.

Unfortunately, very few helmets found in this area have been analyzed to know its metallographic composition, although the data obtained from the analyses carried out to the specimens from the mouth of the Guadalquivir and from Malaga show that they were made of binary bronze $(\mathrm{Cu}-\mathrm{Sn})$ with a low percentage of tin, which in the first case is between 12-13\% and the second also in a low proportion although, as indicated above, is not specified. These data are in line with those obtained for other specimens from Greece itself, as happens with a helmet from the sanctuary of Olympia in the Museum of Manchester whose percentage of tin is between $11-12 \%^{38}$, to which we can add a set of 21 items, also ritually deposited in that shrine, which have recently been published and were between $7.8 \%$ and $12.8 \%$ of the same metal, yielding an average rate of $10.3 \%$, including slight variations when other methods have

34. J. Mancebo Dávalos, Armas defensivas en el Bajo Guadalquivir durante el período tartésico, 1998, 29; R. Olmos Romera, "El casco griego de Huelva" ["The Huelva Greek helmet"], in El casco griego de Huelva, ed. J. Albelda, and H. Obermaier (Huelva, Diputación de Huelva, 1931), 48-51; R. Graells i Fabregat, and A. J. Lorrio Alvarado, "Helmets in the waters of the Iberian Peninsula: ritual practices and data for discussion," in Waffen für die Götter. Waffenweihungen in Archäologie und Geschichte, ed. M. Egg, A. Nasoand R. Rollinger (Innsbruck 6.-8. März 2013, 2016), 143-146.

35. J. L. de Madaria, "Casco militar" ["Military helmet"], in Argantonios. Rey de Tartessos (Madrid, Ministerio de Educación y Cultura, 2000), 262.

36. Graells i Fabregat and Lorrio Alvarado, op. cit. 161 and 167.

37. P. Manti, Shiny helmets: interpretation of tinning, manufacture and corrosion of Greek helmets (7th - 5th c BC), PhD thesis, (Cardiff, Cardiff University, 2011), 112.

38. A. Tiemblo Magro, Un nuevo casco griego de bronce posiblemente hallado en España, 1994, 34; C. Rodríguez Segovia, and E. Núñez Pariente de León, Estudio y restauración del casco griego del museo de Málaga, 2015, 137-138; E. Pantos, et al., "Neutron and X-ray characterisation of the metallurgical properties of a 7th century BC Corinthian-type bronze helmet," Nuclear Instruments and Methods in Physics Research, B 239(2005): 16-26; E. Pantos et al., "Synchrotron radiation and neutron study of a 7th -century BC Corinthian-type helmet at The Manchester Museum," in Non-destructive testing and analysis of museum objects (Cost, Brussels, 2006), 25-30; A. J. N. W. Prag et al., "How the Greeks Got Ahead: Technological Aspects of Manufacture of a Corinthian Type Hoplite Bronze Helmet from Olympia," in Science and Technology in Homeric Epics (History of Mechanism and Machine Science) (Patras: University of Patras), 2008: 205-220. 
been used for metallographic analysis and offering similar values ranging from $7.81 \%$ to $11.80 \%$ also for their tin content ${ }^{39}$.

\section{Conclusions}

As we have seen, despite its geographical remoteness from the Greek territory, the south of the Iberian Peninsula has provided an interesting Greek armament set consisting of four Corinthian helmets and a front plate of a cuirass of the muscle type, which can be dated between the $7^{\text {th }}$ and the $6^{\text {th }}$ centuries BC. Regarding the helmets we should express that the oldest would be the one from the Guadalete River as it has been dated in the early decades of the $7^{\text {th }}$ century, placing the rest in the middle of the next century, relegating the only documented cuirass to the last decades of this century. These helmets come from very different contexts, as three of them have been found in aquatic environment and can be related to ritual practices carried out in the sphere of the Tartessian society, while the fourth comes from a Phoenician colony as Malaca and the cuirass may be associated with a Phoenician ship sunk in waters of ancient Sexi, being the latter a very important aspect when assessing what commercial agents could have brought these materials to these territories.

As for the centres where these pieces were manufactured we should point out the Peloponnese for the Guadalete River helmet, the earliest, as we have seen, while those from Huelva, Sanlucar de Barrameda and Malaga should be related to Greek colonies founded in southern Italy, where we can check a transfer of production centres to more western areas with the passage of time. Unfortunately, we hardly find any analysis on the metallographic composition of these objects, because they have only been made to the Guadalquivir and Malaga helmets, which show that it is a binary bronze with a small proportion of tin, a fact that is coincident with the data provided by other helmets found outside the area under study. We believe that, in the same way as the pottery, everything suggests that those pieces came to these shores as a result of Phoenician trade, not necessarily associated with Greek population, particularly mercenaries, but on the contrary, it seems they were destined to the ruling elites of Phoenician or indigenous communities settled in the south of the Iberian Peninsula. However, this circumstance is not an obstacle for Greek merchants to have also participated in this trade, perhaps Phocaean commercial agents whose contacts with the southern Iberian Peninsula population are well documented, especially in coastal areas such as Malaga or Huelva ${ }^{40}$.

39. P. Manti, Shiny helmets: interpretation of tinning, manufacture and corrosion of Greek helmets (7th - 5th c BC), 2011, 151-154 and 162-163.

40. R. Olmos Romera, "Los griegos en Tartessos: una nueva contrastación entre las fuentes arqueológicas y las literarias" ["Greeks in Tartessos: a new corroboration between archaeological and literary sources"], in Tartessos. Arqueología protohistórica del Bajo Guadalquivir (Barcelona: editorial Ausa, Barcelona, 1989), 501-502 and 509; A. D. Domínguez Monedero, "Fenicios y griegos en el sur de la Península Ibérica en época arcaica" ["Phoenicians and Greeks in the south of the Iberian Peninsula in archaic times from Onoba to Mainake"], Mainake, XXVIII(2006): 62-64. 


\section{Bibliography}

Alvar Ezquerra, J. "Los medios de navegación de los colonizadores griegos" ["The navigation methods of Greek settlers"]. Archivo Español de Arqueología, 52, no. 1(1979): 69-83.

Amandry, P. "Casques grecs à decor gravé" ["Greek helmets with engraved decoration"]. Bulletin de Correspondance Hellénique, 73(1949): 437-446.

Aquilué, X. "Las colonias griegas en Iberia" ["The Greek colonies in Iberia"]. In Iberia Graeca. El legado arqueológico griego en la Península Ibérica. Girona, Centro Iberia Graeca, 2012.

Arribas, A., Trías, G., Cerdá, D. and Hoz, J. de. El barco de El Sec (costa de Calviá, Mallorca). Estudio de materiales [The Sec ship (Calviá coast, Majorca). Study of material remains]. Palma de Mallorca, Ayuntamiento de Calviá, 1987.

Arribas, A. and Arteaga, O. El yacimiento fenicio de la desembocadura del río Guadalhorce (Málaga) [The Phoenician site on the Guadalhorce river mouth (Málaga)]. Granada, Universidad de Granada, 1975.

Aubet Semmler, M. E. "Marfiles fenicios del Bajo Guadalquivir (y III): Bencarrón, Santa Lucía y Setefilla" ["Phoenician ivories from Lower Guadalquivir (and III): Bencarrón, Santa Lucía and Setefilla"]. Pyrenae. Revista de Prehistoria $i$ Antiguitat de la Mediterrània, 17-18, (1980-81): 231-279.

Aubet Semmler, M. E. "Mainake, la primera Malaka" ["Mainake, the first Malaka"]. In Tuvixeddu, la necropoli occidentale di Karales, edited by E. Cagliari de la Torre, 2000.

Bartoloni, P. "L'esercito, la marina e la guerra" ["The army, the navy and the war"]. In Ifenici, Milano: ed. Bompiani, 1988.

Barril Vicente, M. "Cascos hallados en necrópolis celtibéricas conservados en el Museo Arqueológico Nacional de Madrid" ["Helmets found in Celtic-Iberian necropolises preserved in Madrid National Archaeological Museum"]. Gladius. Estudios sobre armas antiguas, armamento, arte militar y vida cultural en oriente y occidente, XXIII, (2003): 5-60.

Blázquez Martínez, J. M. "Dios jinete púnico sobre disco de Ibiza" ["Punic rider god on a disc from Ibiza"]. Zephyrus. Revista de Prehistoria y Arqueología, 17(1966): 101-103.

Blázquez Martínez, J. M. "Escarabeos de Ibiza" ["Ibiza scarabs"]. Zephyrus. Revista de Prehistoria y Arqueología, 21-22(1970-1971): 315-319.

Cienforini, A. C. "La cultura de los príncipes" ["The culture of the princes"]. In Los etruscos, Madrid, Ministerio de Cultura 2013.

Collado Hinajeros, B. Guerreros de Iberia. La guerra antigua en la Península Ibérica [Iberian Warriors. Ancient war in the Iberian Peninsula]. Madrid: La Esfera de los Libros, 2018.

Domínguez Monedero, A. J. "Fenicios y griegos en occidente: modelos de interacción" ["Phoenicians and Greeks in the west: interaction models"]. In Contactos en el extremo de la Oilouméne. Los griegos en occidente y sus relaciones con los fenicios. Ibiza, Museo de Ibiza, 2003.

Domínguez Monedero, A. D. "Fenicios y griegos en el sur de la Península Ibérica en época arcaica. De Onoba a Mainake" ["Phoenicians and Greeks in the south of the Iberian Peninsula in archaic times. From Onoba to Mainake"]. Mainake, XXVIII(2006): 49-78.

Fernández Jurado, J. La presencia griega arcaica en Huelva [The archaic Greek presence in Huelva]. Huelva, Diputación Provincial, 1984. 
García, D. "Le casque corinthien des Baux-de-Provence" ["The Corinthian helmet from Baux-de-Provence"]. In L'Occident Grec de Marseille à Mègara Hyblaea. Arles: ed. Errance, 2013.

García González, D., López Chamizo, S., Cumpián Rodríguez, A. and Sánchez Bandera, P. J. "La tumba del guerrero. Un hallazgo de época protohistórica en Málaga" ["The warrior's grave. A protohistoric times finding in Málaga"]. Mainake, XXXIV(2013): 277-292.

García y Bellido, A. Los hallazgos griegos en España [Greek findings in Spain]. Madrid, 1936.

Giménez, E. M. "Aproximación al estudio de la cerámica ibérica en el Bajo Aragón: relaciones comerciales, importaciones y clasificación" ["Approach to the study of Iberian pottery in Lower Aragón: relations, imports and classification"], Salduie. Estudios de Prehistoria y Arqueología, no. 10(2010): 73-88.

González de Canales Cerisola, F. "El lejano occidente en la cosmografía mítica griega anterior al viaje de Coleo de Samos" ["The far west in the Greek mythical cosmography before Colaeus of Samos voyage"]. Huelva en su Historia, 7(1999): 9-24.

Graells i Fabregat, R. Mistophori ex Iberias. Una aproximación al mercenariado hispano a partir de las evidencias arqueológicas (s.VI-IV a. C.) [Mistophori ex Iberias. Approach to the hispanic mercenary armies from the archaeological evidence (6th-4th cent. BC)]. Venosa, Osanna Edizioni, 2014.

Graells i Fabregat, R. and Lorrio Alvarado, A. J. "El casco celtíbero de Muriel de la Fuente (Soria) y los hallazgos de cascos en las aguas de la Península Ibérica" ["The Celtic-Iberian helmet from Muriel de la Fuente (Soria) and the findings of helmets in waters of the Iberian Peninsula"]. Complutum, 24, no. 1(2013): 151-173.

Graells i Fabregat, R. and Lorrio Alvarado, A. J. "Helmets in the waters of the Iberian Peninsula: ritual practices and data for discussion." In Waffen für die Götter. Waffenweihungen in Archäologie und Geschichte, edited by M. Egg, A. Naso and R. Rollinger. Innsbruck 6.-8. März 2013, 2016: 143-152.

Jiménez Ávila, F. J. La toréutica orientalizante en la Península Ibérica [The orientalising bronze work in the Iberian Peninsula]. Madrid, Real Academia de la Historia, 2002.

López Grande, M. I., Velázquez, F., Fernández, J. H. and Mezquida, A. Amuletos de iconografía egipcia procedentes de Ibiza [Amulets with Egyptian iconography from Ibiza]. Ibiza: Museo de Ibiza, 2014.

Madaria, J. L. de "Casco militar" ["Military helmet"]. In Argantonios. Rey de Tartessos, Madrid, Ministerio de Educación y Cultura, 2000: 262.

Maluquer de Motes, J. "La coraza griega de bronce, del Museo de Granada" ["The Greek bronze cuirass from Granada Museum"]. Zephyrus. Revista de Prehistoria y Arqueología, XXV(1974): 321-327.

Mancebos Dávalos, J. "Armas defensivas en el Bajo Guadalquivir durante el período tartésico" ["Defence weapons in Lower Guadalquivir during the Tartessian period"]. Antiquitas, 9(1998): 25-30.

Manti, P. Shiny helmets: interpretation of tinning, manufacture and corrosion of Greek helmets (7th - 5th c BC), PhD thesis, Cardiff, Cardiff University, 2011.

Martín Ruiz, J. A. Catálogo documental de los fenicios en Andalucía [Documentary catalogue of Phoenicians in Andalusia]. Seville, Junta de Andalucía, 1995.

Martín Ruiz, J. A. "Malaca." In Dizionario Enciclopedico della Civiltà Fenicia. An Encyclopedia Dictionary of the Phoenician Civilization, edited by P. Xella, Roma, C. N. R., 2014: 1-6. 
Olmos Romera, R. "El casco griego de Huelva" ["The Huelva Greek helmet"]. In $E l$ casco griego de Huelva, edited by J. Albelda, and H. Obermaier. Huelva, Diputación de Huelva, 1931: 39-79.

Olmos Romera, R. "Los griegos en Tartessos: una nueva contrastación entre las fuentes arqueológicas y las literarias" ["Greeks in Tartessos: a new corroboration between archaeological and literary sources"]. In Tartessos. Arqueología protohistórica del Bajo Guadalquivir. Barcelona: ed. Ausa, 1989.

Pantos, E., Kockelmann, W., Chapon, L. C., Lutterotti, L., Bennett, S. L., Tobin, M. J., Mosselmans, J. F. W., Pradell, T., Salvado, N., Butí, S., Garner, R. and Prag, A. J. N. W. "Neutron and X-ray characterisation of the metallurgical properties of a 7th century B C Corinthian-type bronze helmet." Nuclear Instruments and Methods in Physics Research, 239(2005): 16-26.

Pantos, E., Kockelmann, W., Chapon, L. C., Lutterotti, L., Bennett, S. L., Prag, A. J. N. W., Mosselmans, J. F. W., Pradell, T., Salvado, N., Buti, S., Garner, R. and Prag, A. J. N. W. "Synchrotron radiation and neutron study of a 7th-century BC Corinthian-type helmet at The Manchester Museum." In Non-destructive testing and analysis of museum objects. Brussels, Cost, 2006: 25-30.

Parker, A. J. Ancient Shipwrecks of the Mediterranean and the Roman Provinces. Oxford: B.A.R, 1992.

Pemán, C. Hallazgo de un casco griego en el Guadalete y recapitulación de testimonios sobre la presencia de los griegos en Andalucía en los siglos VII-VI a. C. [Finding of a Greek helmet in the Guadalete and recapitulation of testimonies about the presence of Greeks in Andalusia in th 7th-6th centuries]. Cádiz, 1938.

Pflug, H. "Korinthische Helme" ["Corinthian helmet"]. In Antike Helme. Sammlung Lipperheide und andere Bestände des Antikenmuseums Berlin. Monographien des RGZM, 14, Mainz, 1988: 65-106.

Prag, A. J. N. W., Garner, R., Pantos, E., Bennett, S. L., Mosselmans, J. F. W., Tobin, M. J., Kockelmann, W., Chapon, L. C., Salvado, N. and Pradell, T. "How the Greeks Got Ahead: Technological Aspects of Manufacture of a Corinthian Type Hoplite Bronze Helmet from Olympia." In Science and Technology in Homeric Epics (History of Mechanism and Machine Science). Patras: University of Patras, 2008.

Ramón Torres, J. Las ánforas fenicio-púnicas del Mediterráneo central y occidental [The Phoenician-Punic amphorae in Central and Western Mediterranean]. Barcelona: Universitat de Barcelona, 1995.

Rodríguez Segovia, C. and Núñez Pariente de León, E. "Estudio y restauración del casco griego del museo de Málaga" ["Study and restoration of the Greek helmet from Málaga Museum"]. PH Investigación. Revista del IAPH para la investigación del patrimonio cultural, 88(2015): 128-145.

Tiemblo Magro, A. "Un nuevo casco griego de bronce posiblemente hallado en España" ["A new bronze Greek helmet possibly found in Spain"]. Revista de Arqueología, 158(1994): 32-35.

Trías de Arribas, G. Cerámicas griegas de la Península Ibérica [Greek pottery from the Iberian Peninsula]. Valencia: The William L. Bryant Foundation, 1966.

Zyguslki Jr., Z. "Armour as a Symbolic Form." Waffen und Kostümkunde, 26, no. 2(1984): 77-96. 
